\title{
Money also is sunny in a retiree's world: financial incentives and work after retirement
}

Svenja Lorenz ${ }^{1}$ and Thomas Zwick T. $^{1,3^{*}}$ (D)

\begin{abstract}
This paper assesses the impact of financial incentives on working after retirement. The empirical analysis is based on a large administrative individual career data set that includes information about $2 \%$ of all German employees subject to social security or in marginal employment until age 67 and their employers in the period 1975-2014. We use the classical labor supply model and differentiate between the impact of (potential) labor and non-labor (pension entitlements) income. A Heckman-type two step selection model corrects for endogeneity. We show that labor income has a positive and non-labor income a negative impact on the decision to work after retirement. Especially individuals who can substantially increase their earnings in comparison to their pension entitlements accordingly have a higher probability to work. Men are more attracted by labor earnings incentives than women. Also individuals who work until retirement are easier attracted to work after retirement by higher labor income than those with gaps between employment exit and retirement. Our results allow the calculation of the impact of changes in taxes on labor and non-labor income and changes in earnings offers by employers on work after retirement for different demographic groups.
\end{abstract}

Keywords: Work after retirement, Financial incentives, Labor and non-labor income

JEL Classification: J14, J22, J26

\section{Introduction}

Labor force participation of retirees increased strongly in most European countries in recent years (Eurofound 2012; Hofäcker and Naumann 2015). On average, the employment rate for individuals aged between 65 and 74 years has risen from $5.2 \%$ in 2002 to $8.7 \%$ (an increase of 67\%) in 2014 in the EU-15 Countries (Rhein 2016). ${ }^{1}$

Individual, social and work-related push and pull factors have been put forward as drivers of post-retirement employment in a dynamically developing strand of

\footnotetext{
${ }^{1}$ Also in Germany, the labor force participation rate of people aged 65 to 74 increased to $9.6 \%$ in 2014 from $4.2 \%$ in 2002, implying a rise of almost $140 \%$ (Rhein 2016).
}

scientific literature (Anger et al. 2018; Burkert and Hochfellner 2017; Büsch et al. 2010; Cahill et al. 2015; Fasbender et al. 2016; Maxin and Deller 2010; Micheel et al. 2010; Pleau and Shauman 2013; Wang et al. 2008; Westermeier 2019).

This paper concentrates on the impact of financial incentives of older individuals on their decision to work after retirement or not. More specifically, we estimate the percentage change in labor force participation after retirement in response to a percentage change in the financial situation. On the basis of a Heckman (1976, 1979) approach to correct for sample selection, we show that (potential) labor earnings are an important pull factor for the decision to engage in employment beyond

*Correspondence: thomas.zwick@uni-wuerzburg.de

${ }^{1}$ Faculty of Business Management and Economics, University

of Würzburg, Sanderring 2, 97070 Würzburg, Germany

Full list of author information is available at the end of the article

Springer Open

(c) The Author(s) 2021. Open Access This article is licensed under a Creative Commons Attribution 4.0 International License, which permits use, sharing, adaptation, distribution and reproduction in any medium or format, as long as you give appropriate credit to the original author(s) and the source, provide a link to the Creative Commons licence, and indicate if changes were made. The images or other third party material in this article are included in the article's Creative Commons licence, unless indicated otherwise in a credit line to the material. If material is not included in the article's Creative Commons licence and your intended use is not permitted by statutory regulation or exceeds the permitted use, you will need to obtain permission directly from the copyright holder. To view a copy of this licence, visit http://creativecommons.org/licenses/by/4.0/. 
retirement. We separately assess the second main financial incentive mechanism and find that there is a sizeable negative pension entitlement (non-labor income) effect on the probability of working after retirement. As a consequence, we show that the higher the ratio between (potential) post-retirement labor earnings and pension entitlements, the larger the likelihood of post-retirement employment. The second aim of the paper is the provision of empirical evidence of heterogeneous earnings elasticities between retiree groups. We show that women are less responsive to higher labor earnings than men. Especially men with low earnings before retirement have high earnings elasticities. We in addition find that individuals who use the bridge options partial retirement or unemployment before early retirement are less responsive to higher labor earnings after retirement than their counterparts who work until retirement.

This paper makes the following contributions to the literature on empirical determinants of work beyond retirement: first, we empirically assess the importance of labor earnings in comparison to non-labor income for work beyond retirement for the first time. Second, large-scale and reliable administrative social security panel data covering all types of employees except civil and military servants are used instead of small-scale and potentially specific sub-populations or survey-based data that were the basis of most relevant studies so far. ${ }^{2}$ Third, a rich set of employer and individual characteristics allows us to control for additional determinants of work beyond retirement. Fourth, based on hypotheses, we show heterogeneities in labor earnings elasticities between men and women, employees who have their work and home in the same region or not, employees with and without a gap between employment exit and retirement, and employees with high and low earnings before retirement. The analysis of differences in elasticities between these sub-groups allows us to derive more specific implications of changes in financial incentives for these sub-groups.

\section{Background}

\subsection{Financial situation as driver of work after retirement}

There are strong indications that the individual financial situation is a key driver of work after retirement. ${ }^{3}$ More specifically, Hochfellner and Burkert (2013) and Pleau and Shauman (2013) find a negative correlation between pension entitlements and work after

\footnotetext{
${ }^{2}$ Examples are the German Ageing Survey (Deutscher Alterssurvey DEAS) or the Survey of Health, Ageing and Retirement in. Europe (SHARE).

${ }^{3}$ We only briefly summarize the literature on the impact of financial situation on working after retirement. There are several recent literature reviews that describe the knowledge about other drivers, compare for example Engstler and Romeu-Gordo (2014) or Sullivan and Al Ariss (2019).
}

retirement-Kanabar (2015) however does not find this correlation. Micheel et al. (2010) stress a negative correlation between equivalent household income before retirement and the interest in work after retirement-Engstler and Romeu-Gordo (2014) however find a u-shaped pattern for work after retirement and equivalent household income. Maestas (2010) finds a weakly positive correlation between the decision to unretire and earnings before retirement. Komp et al. (2010) and Kanabar (2015) find no correlation between working after retirement and (non-pension) wealth. Engstler and Romeu-Gordo (2014) point to the fact that higher financial pressure such as the presence of a real estate loan also can explain work after retirement.

When looking closer at the measurement of the financial situation of retirees, it becomes evident that so far no contribution on work after retirement made a distinction between labor and non-labor income. Some papers only include non-labor income after retirement such as pension entitlements (Hochfellner and Burkert 2013; Kanabar 2015). Other papers bundle up non-labor and labor income after retirement by for example using equivalent household income after retirement (Anger et al. 2018; Engstler and Romeu-Gordo 2014; Micheel et al. 2010; Pfarr and Maier 2015). A last group of papers looks at wealth or the subjective economic status before retirement (Fasbender et al. 2016; Kanabar 2015; Komp et al. 2010; Wang et al. 2008).

Empirical approaches that do not separate labor and non-labor earnings after retirement may report biased results on financial determinants of work participation after retirement. According to standard labor supply theory, labor earnings are assumed to increase work participation and non-labor income is assumed to decrease it (Cahuc et al. 2004; Blundell et al. 2007). When work has a higher reward, workers substitute leisure against work. An increase in non-labor income has a negative effect on work participation or working hours. The income effect induces employees to reduce work because they can maintain a target standard of living with lower labor burden. This paper for the first time distinguishes between income and substitution effects of work and non-work income after retirement on work participation and shows the empirical relevance of both drivers.

The extensive labor supply margin response to marginal work income changes depends on the probability density function of the distribution of reservation wages around the economy's equilibrium. The variance in labor supply for small changes in wages around the equilibrium wage is low for the entire working-age population because relatively few people who do not work are willing or able to work for the current wage (Chetty et al. 2011). It is therefore hard to estimate reliable earnings 
elasticities on labor supply for the working-age population. Relatively many employees at the end of their career are closer to the margin of re-entering the labor force for available earnings opportunities, however. As the previous labor contract ends when entering retirement, all employees close to retirement have to decide whether to work in a new labor contract or not besides receiving retirement benefits. Upon retirement, labor re-entry incidence and potential extensive margin responses to labor earnings options therefore are relatively high in comparison to the earnings elasticity for the entire population (Rogerson and Wallenius 2009).

Analogously to people close to retirement, all women with a small child have to decide whether to work again or continue to provide full time childcare. As a consequence, also the extensive margin response to labor earnings incentives is relatively high (and easier to measure) for women with small children. The empirical literature on mothers with young children shows that besides nonlabor financial means such as income received by other household members, childcare cost subsidies or public transfers such as parental allowance, also (potential) labor earnings are an important driver of labor market re-entry (Allègre et al. 2015; Borra 2010; Connelly 1992; Del Boca and Vuri 2007; Ribar 1992; Viitanen 2005). The empirical identification strategy to analyze financial incentives on labor supply of mothers after their parental leave period can be applied to the labor supply decision of older workers after their retirement. As a consequence, we use the Heckman selection model proposed for example by Connelly (1992) or Borra (2010) and assume that for retirees, (potential) labor earnings are an important driver for work after retirement besides non-labor earnings.

\subsection{Basic model}

According to the standard labor supply model, retirees maximize their utility by comparing consumption made possible by labor and non-labor income with leisure (Cahuc et al. 2004). In the case of work after retirement, individuals decide whether to work or not after they receive an old-age pension. ${ }^{4}$ The observation period therefore starts at the earliest at the early retirement age (ERA) for those eligible for an early retirement option or at the normal retirement age (NRA) for the other employees. Figure 1 shows different possible budget lines as well as the retirees' corresponding indifference curves. The slope of the indifference curves $\left(U_{A}, U_{B}, U_{C}, U_{D}\right)$ defines the marginal rate of substitution between consumption

\footnotetext{
${ }^{4}$ Please note that "not working" when receiving an old-age pension means for many individual in our dataset to be engaged in unpaid care, household or volunteer work or being self-employed.
}

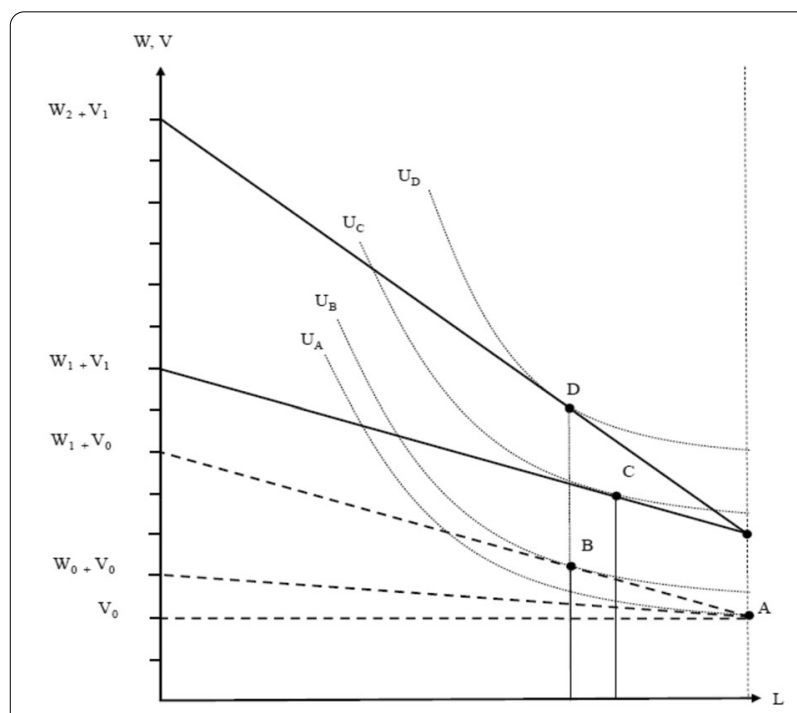

Source: own illustration.

Fig. 1 Labor supply model of retirees (Source: own illustration)

and leisure. The shape of the indifference curves corresponds to consumption and leisure being defined as "normal" goods with decreasing marginal returns.

In this model, individual income consists of non-labor income (in our case pension entitlements) $V$ and labor earnings $W$. The earnings derived from work after retirement correspond to the opportunity costs of leisure. The point where one of the retiree's indifference curves tangents the budget line is the combination of earnings and leisure with which the retiree maximizes utility under the budget constraint.

Figure 1 shows that if potential (hourly) labor earnings after retirement are too low, the individual does not work after retirement. The maximum indifference curve, $U_{A}$ crosses the budget line at point $A$ and the retiree consumes only non-labor earnings $V_{0}$. If (hourly) labor earnings and accordingly the slope of the budget line increase, utility is maximized at point $B$ with $U_{B}>U_{A}$. The retiree therefore decides to work after retirement (substitution effect) and we can derive the following hypothesis:

Hypothesis 1 The higher the (potential) labor earnings after retirement, the greater the likelihood to work after retirement.

An increase in non-labor income from $V_{0}$ to $V_{1}$ results in a parallel shift of the budget line. With higher nonlabor income, labor force participation decreases because the retiree can now consume the same quantity of goods when working less (income effect). In Fig. 1, the income effect is depicted by steeper indifference curves at a given 
leisure level with increasing V. Thus, an increase in the pension entitlements decreases the opportunity cost of leisure. In Fig. 1 an increase in the pension entitlements is illustrated as a shift from point $B$ to point $C$. Note that with an increase in $V$ that is strong enough, at a given labor earnings level, pensioners may decide to stop working. Therefore, the following hypothesis is derived:

Hypothesis 2 The higher the pension entitlements (non-labor income), the lower the likelihood to work after retirement.

Given the higher pension entitlement, $V_{1}$, higher (potential) labor earnings ( $W_{2}$ instead of $\left.W_{1}\right)$ are needed to incentivize the retiree to work as much as in point B (point D, for example). A higher substitution effect (higher labor earnings) has to compensate for a higher income effect (higher non-labor income) for labor market participation after retirement. Hypothesis 3 combines the first two hypotheses:

Hypothesis 3 The higher the ratio between the (potential) labor earnings after retirement and non-labor income, the greater the likelihood that the retiree works after retirement.

\subsection{Heterogeneous responses to financial incentives}

We now derive factors that explain differences in labor earnings elasticities for the labor force participation between retiree groups. Arguments concerning different responses of individuals to financial incentives from labor supply theory and existing empirical results on post-retirement employment are built upon to derive hypotheses that can be tested in the empirical analysis.

In the labor supply literature, a robust finding is that earnings elasticities of women exceed that of men (Bargain et al. 2014; Evers et al. 2005; Meyer and Rosenbaum 2001). The difference between gender groups is explained by the division of labor within the family (Blundell et al. 2007). According to Blau and Kahn (2007) and Mincer (1962), women substitute their time between market work, home production, and leisure, whereas men primarily substitute their time between market work and leisure. As women have closer substitutes for market work than men, they are expected to have larger earnings substitution effects. The literature therefore points out that household production increases the elasticity of labor supply because home-made goods are substitutes for commercial goods (Cahuc et al. 2004; Mincer 1962).

At first sight, the labor supply mechanisms for all individuals in working age also apply for retirees. The share of older women engaged in household production (e.g., care of relatives, childcare of grandchildren) is higher than the comparable share of men (Hank and Buber 2009). In addition, there is a second spike in household production when individuals approach retirement age. This spike is larger for women than for men, see Vargha et al. (2017). There is a decisive difference between the average individual in working age and the decision for work after retirement when calculating the employment earnings elasticities, however. Until retirement, the share of men who do not work is much smaller than the share of women (Blau and Kahn 2007). The labor market attachment of men who potentially can join the workforce therefore is lower than that of women. Hence, the earnings elasticity of males during their working age on average is lower than the earnings elasticity of females (Bastani et al. 2021). On day 1 after retirement, labor market participation of men and women is set to zero, however. As a consequence, there may be more males willing to re-enter work after retirement than females at available labor earnings given the higher home production duties of women that make labor market participation less attractive or impossible for them. In other words, the density of male retirees to re-enter employment may be higher than the density of female retirees.

Therefore, we assume that the labor earnings elasticity for old women is lower than that for old men:

Hypothesis 4 Women have lower post-retirement labor earnings elasticities than men.

Some previous papers on the decision to work after retirement look at potential differences between men and women. As financial drivers however only individual and equivalent household income before retirement as well as wealth and pension entitlements have been included but not our key variable (potential) labor earnings. Pleau (2010) and Pleau and Shauman (2013) stress that women with a high individual income before retirement more often work after retirement. Equivalent household income and wealth seem to play no role for women. For men however work after retirement is positively correlated with equivalent household income and negatively with wealth (but not individual income). Engstler and Romeu-Gordo (2014) however find an impact of pension entitlements for men only.

In Germany, there are various ways to transit from employment to retirement (Rasner and Etgeton 2014). A substantial portion of older workers have a gap between employment exit and retirement entry. This gap is called "bridge option" if individuals do not withdraw from the labor market between the exit from their last employment and retirement (Brussig 2015). There are two bridge options, an unemployment spell between work exit and 
(early) retirement and partial retirement. Partial retirement may mean that employees work full time for half the partial retirement period at reduced earnings and exit employment completely for the second half. The socalled block model version of partial retirement has been chosen by more than $80 \%$ of participants (Brussig 2015). A much smaller share of retirees chose the so-called continuous version of partial retirement. Here the employee reduced working-time to half during the entire partial retirement period and no gap between labor market exit and pension entry occurs. ${ }^{5}$ Both bridge options can be used by employees after 15 contribution years to pension retirement and at least 8 years of contributions periods in the last 10 years before retirement. Bridge options therefore are not viable for employees with large labor market gaps and a low labor market attachment in general.

In both bridge options, employees usually have to accept financial disadvantages in comparison to their other (early) retirement options, but they can exit employment already before their ERA (Lorenz et al. 2020). Indeed, labor market exit age on average is between one to two years earlier for those using partial retirement or retirement after unemployment than for those choosing the early retirement options without employment gaps before retirement that also would have been available for those who used bridge options (Geyer et al. 2021). ${ }^{6}$ For those who use both bridge paths, we hardly observe a return to regular employment before retirement. We therefore assume that employees who choose a bridge option put a relatively high value on leisure at old age and they therefore are less inclined to work after retirement. A lower inclination to work after retirement also has been found for those who did not work full time until retirement (Burkert and Hochfellner 2017; Maestas 2010; Smeaton and McKay 2003)those who use the so-called continuous version of partial retirement are a case in point for part-time work before retirement.

The argument that employees who select partial retirement have a higher value of leisure seems to be obvious because employees have to give their consent for trading earnings against an earlier employment exit (Wanger

\footnotetext{
${ }^{5}$ Please note that the concept of bridge employment in Germany differs from that used in the US (Beehr and Bennett 2015). In Germany, bridge employment means that employees exit employment earlier then retirement or reduce their working time in their career job or they exit into unemployment from their career job before they enter retirement. In the US, bridge employment usually means taking another job after their career job.

${ }^{6}$ Almost all employees in bridge options in the cohorts we look at also are entitled to use other early retirement options such as the pension for women and the pension for the long-term insured. Indeed, many employees in bridge options used these alternative early retirement options after their bridge option.
}

2009). Employers therefore are more successful in nudging employees with a lower labor market attachment at old age into partial retirement. The group of employees who bridge the time between employment and retirement by unemployment may mainly consist of workers who have been dismissed against their wills and therefore their value of leisure is unclear. The German labor law especially protects employees with high tenure and/ or experience against dismissal, however (Ullmann and Bothfeld 2008). In addition, many judges in labor courts are employee-friendly in dismissal disputes. As a consequence, the appeal against an involuntary dismissal before a labor court has a high success rate especially for older workers. Employers are exposed to high uncertainty with respect to the outcome of the lawsuit that easily takes more than 1 year (Ullmann and Bothfeld 2008) and they frequently face a detrimental effect on their reputation when they unilaterally dismiss older employees. Therefore, only a very small share of older employees is dismissed against their will ${ }^{7}$ and most dismissed older employees obtain substantial severance pay (Schmähl 2003; Grund 2006). Severance and compensation payments for a dismissal or partial retirement however are subject to individual bargaining between employer and employee. Therefore, employers may prefer to nudge employees with a relatively strong preference for leisure into unemployment before early retirement because dismissing them is cheaper. ${ }^{8}$ Our fifth hypothesis is:

Hypothesis 5 Individuals using bridge paths into retirement have lower earnings elasticities than individuals who are employed until retirement.

Individuals with different places of work and residence before retirement accept commuting costs. According to labor supply theory, at given earnings, commuting costs reduce the opportunity cost of leisure and therefore reduce labor supply (Cogan 1977, 1981). Gutiérrez-i-Puigarnau and van Ommeren (2010) assume a strict complementarity between commuting costs and labor supply. Their arguments for example

\footnotetext{
${ }^{7}$ Erlinghagen (2005) and Ullmann and Bothfeld (2008) show that the average share of involuntary job terminations was between 20 and 30 percent after 1996 and that the share of involuntary job terminations was strongly negatively correlated with age.

8 This assumption of course applies under the ceteris paribus assumption. We know that partial retirement is mainly accepted by better educated employees who work for large (industrial) employers (Engstler and Romeu-Gordo 2017) and bridge options are mainly offered by employers with higher employee adaptation costs, i.e. large but shrinking employers in regions with high unemployment (Lorenz et al. 2020). It is therefore important to control for the mentioned individual and employer characteristics in order to avoid biased results.
} 
on the negative effects of road pricing on labor supply however are based on the average employee situation in which males work full-time more often than females, commute relatively long distances, and are little affected by economic incentives with respect to their work participation (compare footnote 38 in Gutiérrez-iPuigarnau and van Ommeren 2010). The insights from this paper on the impact of commuting costs and labor supply therefore may not apply for the decision to work after retirement. Given that older employees only work few hours and that they have a time perspective that is too short to look for a new home near a new employer, the necessity to (continue to) commute to a job after retirement may have a negative effect on labor supply. We therefore assume that potential commuting costs of individuals whose place of work is not the place of residence before retirement are higher. This group of employees therefore may be less attracted by financial incentives to work after retirement:

Hypothesis 6 Individuals whose place of work and residence is in the same region before retirement have higher earnings elasticities than individuals who have to commute.

Our last hypothesis concerns heterogeneity by income quartile before retirement. Bastani et al. (2021) show that earnings elasticity decreases with potential earnings. They argue that those with low potential earnings have a lower labor market attachment and therefore their potential for entry into the labor market is higher. For our group of old workers who have to decide whether to re-enter employment, this argument is not valid because their labor market attachment is zero when entering retirement. We however argue that the risk of having pension entitlements below the individual income aspiration level after retirement ("old-age poverty") is higher for those with low labor earnings before retirement (Burkert and Hochfellner 2017). The financial aspect of work after retirement therefore may play a larger role for those who earned less before retirement (Fasbender et al. 2016):

Hypothesis 7 Individuals with lower earnings before retirement have higher earnings elasticities.

\section{Data}

Our analysis is based on a large and high-quality administrative dataset provided by the Federal Employment Agency in Germany (Bundesagentur für Arbeit). The data comprise a sample of $2 \%$ of employees from the Integrated Employment Biographies ranging from
1975 to 2014 (SIAB, 1975-2014)..$^{9}$ Out data therefore only include employees subject to social security and employees in marginal employment ${ }^{10}$ - civil and military servants (around five percent of the workforce) and self-employed (about ten percent of the workforce) ${ }^{11}$ are excluded and unpaid care, household as well as volunteer work is not unfortunately unknown.

The data provide daily information about earnings and employment as well as receipt of benefits according to German Social Books II and III. Moreover, an extensive set of establishment information from the IAB Establishment History Panel is linked to the individual employment history. We know the day at which employees exit from the last employment subject to social insurance contributions before retirement or the day at which the bridge options end. ${ }^{12}$ Individual and company-specific characteristics are measured at this point in time.

We know daily earnings of employees after retirement and whether an employee was in marginal employment or worked more. Earnings from marginal employment and pension entitlements are income tax free and do not require social security contributions in contrast to labor earnings beyond marginal employment. ${ }^{13}$ We want to have comparable earnings indicators for employees in marginal employment and employees with higher earnings. We argue that disposable income is more relevant for the decision of whether to work or not than gross earnings. Therefore, we use net earnings after taxes and social contributions for labor earnings above the marginal employment threshold. More specifically, we deduct earnings taxes for earnings tax class 1 , the solidarity surcharge, church tax and social security contributions to health and nursing care insurance. Approximately $80 \%$ of all employees are in marginal employment after retirement. The share of retired women who have labor earnings beyond the marginal employment level is with $18 \%$ somewhat smaller than the share of men $(22 \%)$.

The age at which pensions can be received in Germany depends on the fact whether the individual is eligible for early retirement or not. There are several early

\footnotetext{
${ }^{9}$ A detailed description of the SIAB can be found in Antoni et al. (2016).

${ }^{10}$ Marginal employment is defined as dependent employment with a maximum monthly salary of 400 EUR (raised to 450 EUR in 2013).

11 The employment shares have been taken from Institut für Arbeit und Qualifikation (2020).

12 In Germany, it is compulsory to report the end of employment to the social insurance system after the statutory retirement age. In the case of employment after retirement, the employer must provide a new contract and submit a new declaration to the social insurance, even if the employee was already employed by the company. Thus, employment is interrupted after pension entry by 1 day (Burkert and Hochfellner 2017).

13 Tax and deduction exemptions on marginal employment were abolished just in 2012.
} 
retirement options that are tied to different requirements such as pension contribution years, gender, or disability. The most important early retirement options are the pension for long-term insured employees, pension for women, pension for severely disabled, and the two bridge options pension after unemployment and pension after partial retirement, see Lorenz et al. (2018) for an indepth description of the early retirement rules and their changes over time. Individuals who are eligible for one or several early retirement options can exit the labor market and start to collect pensions at the ERA specified by the early retirement option (in many cases 60 or 63 years). All other individuals only can collect pensions at the NRA (65 years). People born after 1937 in addition can retire after the NRA. They receive a $6 \%$ increase in pension entitlements for each year of pension postponement.

We cannot observe when individuals start to receive pensions directly in our data and therefore define two groups with employment after receiving a pension. The first group consists of individuals who have a labor market spell after their NRA. The second group consists of individuals who already started a marginal employment before the age of 65 that extends beyond the age of 65 without interruption and who are eligible for early retirement. ${ }^{14}$ We may incur three sources of measurement errors with this identification of individuals who work after retirement. First, some individuals work after NRA without receiving a pension. The number of employees who postponed their entry into retirement after NRA always was negligible. ${ }^{15}$ We include these individuals because they are employed after NRA but incorrectly assume that they also draw pension benefits after age 65 . Second, there may be individuals who receive pensions besides working but stop to work before age 65 . We cannot observe this group of people and therefore our results only cover all individuals who work besides receiving retirement benefits after NRA. The third group works more than marginally before NRA in addition to receiving pensions. This group again is negligibly small because earnings beyond the threshold of marginal employment strongly

\footnotetext{
${ }^{14}$ The SIAB data do not include relevant characteristics of the pension insurance, such as pension entitlements or eligibility. Therefore, individual pension entitlements are calculated and eligibility criteria for old age pensions and the corresponding statutory retirement dates NRA and ERA are identified according to Pfister et al. (2018) and Lorenz et al. (2018). We are grateful to Philip vom Berge and Dana Müller from the FDZ at the IAB for merging the day of birth as part of the Custom Shaped Administrative Data for the Analysis of Labor Market (CADAL) project because the calculation of pension entitlements requires the exact birth date.

15 Bäcker et al. (2017) for example report that in 2014, from about 825,000 retired individuals only about two percent or 22,000 individuals received a bonus.
}

reduce pension claims (Westermeier 2019). Unfortunately, there are no statistics on the incidence of this group.

\subsection{Estimation sample}

Our estimation sample consists of women and men born between 1935 and 1947. For each birth cohort, postretirement employment is observed for a maximum of two years after the NRA. As work incidence quickly declines with age after 65 in Germany (compare for example Pfarr and Maier 2015), we are confident that we do not miss any retirees who start to work in retirement after their 67th birthday. We restrict our sample to WestGerman ${ }^{16}$ men and women with a strong labor market attachment in old age. More specifically, all individuals in the sample must be employed subject to social security at least once after the age of $55^{17}$ and they must be active in the labor market (employed, in partial retirement, or unemployed) at age $59 .{ }^{18}$ The reason for these sample restrictions is to obtain a relatively homogeneous sample of employees who in principle all have the option to work after retirement. The restriction reduces our sample by about $30 \%$.

It is relatively hard in Germany to return to the labor market after longer labor market gaps at higher age-in the group of employees excluded from our sample, the share or employees who work after retirement accordingly is less than one percent. Our sample restrictions also reduce the risk that we include individuals who also were civil servants or self-employed besides or after their employment subject to social security. There are age restrictions on starting a job with a civil servant status and it is hardly possible to work in a job subject to social security besides a job as civil servant. Employers usually do not allow their employees to generate a substantial income from self-employment besides their job subject to social security.

After the sample restrictions we are left with 30,784 women and 44,887 men-we therefore include 75,671 observations. In the sample, 6273 women and 9549 men continue to work after retirement, corresponding to an average of $20 \%$ for women and $21 \%$ for men,

\footnotetext{
${ }^{16}$ Labor market careers are only available for East Germany after January 1, 1991 (Antoni et al. 2016).

17 This sample restriction was also made by Hanel (2010) and Geyer et al. (2021).

18 We also exclude seamen and miners (less than one percent of women and of men) because they have special protection of legitimate expectation rules for retirement that cannot be identified in the dataset.
} 
Table 1 Summary statistics on work and non-work earnings

\begin{tabular}{|c|c|c|c|c|c|c|}
\hline & \multicolumn{2}{|c|}{ Daily net labor earnings (EUR) } & \multicolumn{2}{|c|}{ Daily pension entitlements (EUR) } & \multicolumn{2}{|c|}{$\begin{array}{l}\text { Share of net labor earnings } \\
\text { in pension entitlements (\%) }\end{array}$} \\
\hline & Women & Men & Women & Men & Women & Men \\
\hline \multicolumn{7}{|c|}{ All employees who work after retirement } \\
\hline Mean & 14.013 & $19.770^{* *}$ & 23.016 & $39.122^{* *}$ & 65.94 & $52.97^{* *}$ \\
\hline SD & 14.037 & 24.660 & 9.210 & 11.737 & 60.68 & 65.59 \\
\hline N & 6273 & 9549 & 6273 & 9549 & 6273 & 9549 \\
\hline \multicolumn{7}{|c|}{ Employees with marginal employment after retirement } \\
\hline Mean & 9.406 & 9.514 & 22.637 & $38.510^{* *}$ & 46.93 & $27.06^{* *}$ \\
\hline SD & 3.416 & 3.453 & 8.643 & 10.584 & 24.70 & 15.28 \\
\hline$N$ & 5175 & 7350 & 5175 & 7350 & 5175 & 7350 \\
\hline
\end{tabular}

$S D$ standard deviation, $N$ number of observations

Data: SIAB 7514, own calculations

Significance levels of differences between men and women: ${ }^{*} p<0.05,{ }^{* *} p<0.01$

compare Appendix Table $7 .{ }^{19}$ Across birth cohorts, the share of individuals who work beyond retirement has risen slightly. The number of observations and the share of individuals who continue to work after retirement by birth cohort are shown in Appendix Table 7.

Our data set has some drawbacks such as the absence of information on pension entry and other earnings sources beyond labor earnings and pension entitlements. It however has the advantage of including reliable and largescale information on work behavior of older employees from many birth cohorts. Studies on the relationship between financial incentives and work beyond retirement so far typically relied on small-scale and potentially specific populations (Kim and Feldmann 2000; Saba and Guerin 2005; Torka et al. 2012) or on survey-based data that may be affected by self-selection and measurement error in key variables (Anger et al. 2018; Büsch et al. 2010; Dittrich et al. 2011; Kanabar 2015; Pfarr and Maier 2015, Saba and Guerin 2005).

\subsection{Descriptive statistics}

Our analysis focuses on labor and non-labor financial incentives for employment beyond retirement. The following descriptive statistics accordingly show average daily labor earnings, average pension entitlements, and the average share of labor earnings in pension entitlements by gender and type of employment after retirement (Table 1). The average daily net earnings after

\footnotetext{
19 The proportion of employees who continue to work after retirement is slightly lower than that calculated by Anger et al. (2018). In their study, however, employment after retirement is identified from survey answers. The share of older employees who indicate that they intend to work after retirement in surveys even is between a third and a half (Micheel et al. 2010; Micheel 2021).
}

retirement are 14 EUR for women and 20 EUR for men. ${ }^{20}$ For those who are marginally employed, daily earnings for both sexes are around 9 EUR. Pension entitlements of women who continue to work after retirement are on average $40 \%$ lower than those of men. Of particular interest is the share of labor earnings after retirement in pension entitlements. This share is quite substantial with $66 \%$ for women and $53 \%$ for men. For employees in marginal employment, the share is $47 \%$ for women and $27 \%$ for men. These findings are in line with evidence from the UK where labor earnings after retirement were more than $90 \%$ of average pension entitlements (Kanabar 2015). We therefore conclude that earnings after retirement are an important additional source of income for securing the standard of living in old age. ${ }^{21}$

We also can show that those who continue to work after retirement on average have a significantly lower pension entitlement than individuals who do not work after retirement (Appendix Table 8). This finding corresponds with the negative correlation between non-labor earnings and re-entry into employment after retirement found in most of the previous literature (Burkert and Hochfellner 2017; Büsch et al. 2010; Dittrich et al. 2011; Hochfellner and Burkert 2013; Kim and Feldmann 2000; Micheel et al. 2010). ${ }^{22}$ Appendix Table 8 also summarizes

\footnotetext{
${ }^{20}$ Women have no earnings after retirement above the social contribution earnings threshold and for men the proportion with earnings above the earnings threshold is $0.3 \%$. We therefore do not have to correct for censored earnings.

21 Please note that we cannot take into account other sources of income, such as private and occupation pensions, capital and real estate rents, independent work or savings.

22 Two studies from Germany (Anger et al. 2018; Pfarr and Maier 2015) and one study from England (Kanabar 2015) however show that employees with higher financial means are more likely to work beyond retirement.
} 
differences in individual and establishment characteristics prior to retirement between employees who continue to work after retirement and those who do not. This table shows, for example, that there is a negative correlation between work after retirement and employer size as well as the share of highly skilled workers.

\section{Estimation strategy}

We propose an empirical choice model to examine the decision on working after receiving a pension: accumulated pension entitlements. Pension entitlements indicate the negative income effect in the participation equation and they are an indicator of past labor market performance. Given that all employees obtain a new labor contract, usually entailing less labor hours and new tasks, previous labor market performance is hardly related to (potential) earnings after retirement, compare Appendix Table 9. Pension entitlements therefore can be excluded from the earnings equation.

$$
\begin{array}{ll}
\mathrm{LFP}_{\mathrm{i}}=\beta_{0}+\mathrm{X}_{\mathrm{i}} \beta_{\mathrm{x}}+\mathrm{Z}_{\mathrm{j}(\mathrm{i})} \beta_{\mathrm{z}}+\gamma \mathrm{pe}_{\mathrm{i}}+\delta \widehat{\text { wage }}_{\mathrm{i}}+\varepsilon_{\mathrm{i}} & \mathrm{LFP}=1 \text { if } \mathrm{LFP}^{*}>0 \\
& \mathrm{LFP}=0 \text { if LFP* }=0
\end{array}
$$

The labor force participation variable (LFP) is a dichotomous variable with a value of zero for non-participation (no labor earnings) and a value of one (positive labor earnings) for employment after receiving a pension. The unobservable continuous variable "LFP" reflects the utility difference between non-participation and participation in the labor market beyond retirement. Our main variables of interest are the log disposable pension entitlements " $p e$ " (non-labor earnings) and the net (potential) labor earnings "wage" when receiving a pension. ${ }^{23}$

Labor earnings after retirement may be endogenous because they also reflect time allocation decisions, that is, they are only observed for those who work after retirement. In order to circumvent this endogeneity problem, predicted daily labor earnings after retirement $\widehat{\text { wage }}$ are estimated for all individuals in an auxiliary estimation. The standard Heckman sample selection approach (Heckman 1976, 1979) is used to predict the earnings of post-retirement employment. More specifically, we first estimate a reduced-form post-retirement employment participation Probit model for all individuals in the sample. We use the Probit parameters from this participation equation to generate the inverse Mills ratio. Including this ratio controls for possible sample-selection bias in the wage equation. We then take the results of the wage equation to generate values of the predicted wage for all individuals in the sample (Borra 2010).

Technically, this type of selectivity corrected model can achieve identification by functional form assumptions (Cameron and Trivedi 2002). Nonetheless, most researchers feel more comfortable if at least one regressor in the participation equation is excluded from the labor earnings equation (Connelly and Kimmel 2003; Borra 2010). We accordingly include in the reduced form labor participation equation as exclusion restriction the

\footnotetext{
${ }^{23}$ In a further estimation specification, instead of the expected earnings and the pension entitlements, the ratio of the (potential) earnings in pension entitlements is included in the equation.
}

Besides the exclusion restriction and the Mills ratio in the earnings equation, we include core individual characteristics that have been used in the literature as determinants of work after retirement (Anger et al. 2018; Brenke 2013; Brussig 2010; Burkert and Hochfellner 2017; Engstler and Romeu-Gordo 2017; Fasbender et al. 2016; Hofäcker and Naumann 2015; Larsen and Pedersen 2013; Maestas 2010; Micheel et al. 2017; Rhein 2016; Westermeier 2019). More specifically, we include education, occupation, ${ }^{24}$ accumulated labor market gaps until age 65 in months, ${ }^{25}$ and the year of labor market exit. We keep the auxiliary regressions parsimonious in order to avoid multicollinearity problems in our main labor participation regression (Borra 2010).

In the main labor participation equation, we include all explanatory variables used in the auxiliary participation equations and (potential) labor earnings. In addition, we include dummies that equal one if an individual uses the bridge option partial retirement or unemployment because labor market gaps before retirement negatively affect the continuation of employment after retirement (Anger et al. 2018; Burkert and Hochfellner 2017; Schellenberg et al. 2005; Smeaton and McKay 2003; Westermeier 2019). We also include several characteristics of the last employer before retirement. Previous studies have shown that employees in small establishments have a higher probability of working beyond retirement (Anger et al. 2018; Burkert and Hochfellner 2017; Micheel et al. 2010). In addition, Brussig and Bellmann (2008) show that attitudes towards hiring older workers differ among companies. For example, employees in companies with a high proportion of older employees have a

\footnotetext{
${ }^{24}$ The Blossfeld classification of occupations is intended to form occupational groups as homogeneously as possible with regard to average educational and vocational background and professional fields of activity (Blossfeld 1985).

25 An alternative for the aggregated gaps in the labor market before the age of 65 is the exit age from employment before the statutory retirement age. The results are robust. It is not possible to include both variables in the estimations because they are strongly correlated. Early retirement is associated with more gaps in the labor market before the age of 65 .
} 
Table 2 Linear probability model of labor force participation

\begin{tabular}{|c|c|c|}
\hline Dependent variable: labor force participation & Women & Men \\
\hline \multicolumn{3}{|l|}{ Individual characteristics } \\
\hline Estimated earnings (log) & $0.056^{*}(0.019)$ & $0.246^{* *}(0.055)$ \\
\hline Pension entitlements (log) & $-0.055^{* *}(0.006)$ & $-0.165^{* *}(0.008)$ \\
\hline Bridge option: partial retirement & $-0.078^{* *}(0.007)$ & $-0.060^{* *}(0.005)$ \\
\hline Bridge option: unemployment & $-0.323^{* *}(0.006)$ & $-0.266^{* *}(0.005)$ \\
\hline No degree & Ref. & Ref. \\
\hline Vocational training & $0.032^{* *}(0.006)$ & $0.025(0.013)$ \\
\hline University degree & $0.005(0.012)$ & $-0.075^{*}(0.031)$ \\
\hline Manufacturing occupations & Ref. & Ref. \\
\hline Service occupations & $0.011(0.008)$ & $-0.021(0.014)$ \\
\hline Administrative occupations & $-0.010(0.008)$ & $-0.042^{* *}(0.012)$ \\
\hline Accumulated labor market gaps prior to age 65 in months & $-0.006^{* *}(0.0007)$ & $-0.001(0.001)$ \\
\hline \multicolumn{3}{|l|}{ Employer characteristics } \\
\hline Firm size: $<10$ employees & Ref. & Ref. \\
\hline 10 to 100 employees & $-0.027^{* *}(0.006)$ & $-0.019^{* *}(0.007)$ \\
\hline$>100$ employees & $-0.044^{* *}(0.007)$ & $-0.059^{* *}(0.008)$ \\
\hline Mean imputed earnings of all full-time employees & $-0.0004^{* *}(0.00009)$ & $-0.000006(0.00006)$ \\
\hline Share of highly qualified employees & $-0.027(0.016)$ & $-0.112^{* *}(0.016)$ \\
\hline Share of employees in partial retirement & $-0.204^{* *}(0.061)$ & $-0.128^{* *}(0.049)$ \\
\hline Share of employees aged 55-59 & $-0.030(0.017)$ & $-0.013(0.017)$ \\
\hline Share of employees aged 60-64 & $-0.033(0.023)$ & $-0.065^{* *}(0.021)$ \\
\hline Share of employees aged 65 and older & $0.514^{* *}(0.048)$ & $0.527^{* *}(0.051)$ \\
\hline N & 30,784 & 44,887 \\
\hline$R^{2}$ & 0.307 & 0.210 \\
\hline
\end{tabular}

Additional controls: year of employment exit, and economic sector of the employer. Standard errors in parentheses are computed by bootstrapping with 200 repetitions and are clustered on the individual level. Data: SIAB 7514

${ }^{*} \mathrm{p}<0.05$

**p $<0.01$

higher chance of being hired after their retirement than those in companies with a high proportion of employees in partial retirement and severance payments. Moreover, some studies also use the general economic environment as a determinant of employment after retirement. We therefore include the mean imputed earnings of all full-time employees, economic sector, establishment size, share of employees in partial retirement, share of highly qualified employees, share of employees aged 55-59, share of employees aged 60-64, and the share of employees aged 65 and older.

We take into account that the decision to work after retirement is fundamentally different between men and women because the non-market production situation usually differs between the genders. We therefore estimate all earnings and participation equations separately for men and women.

\section{Estimation results}

\subsection{Employment decision to work beyond retirement}

The first estimation step, the calculation of the earnings equation for all individuals in our sample, is shown in Appendix Table 10. We use potential earnings for individuals who do not work after retirement from this estimation. In the earnings equations, selectivity of employees who decide to work after retirement is taken in account by including the Mills' ratio ("lambda") derived from the parsimonious first-step labor market participation equation. The Hausman specification test checks whether our exclusion restriction is valid to control for endogeneity. The high $\chi^{2}$ values indicate that the pension entitlements variable is a valid exclusion restriction for the labor market participation equation.

We present our estimation results of the second estimation step, the decision to work beyond retirement, in Table 2, separately for women (column I) and men (column II). The OLS estimates suggest a substantial positive effect of the (potential) earnings on labor supply for women and men. According to Hypothesis 1, an increase in (potential) labor earnings by one percent significantly increases the probability of being active in the labor force by 0.056 percentage points for women and by 0.246 percentage points for men, respectively. In other words, an increase in (potential) labor 
earnings by $10 \%$ has the potential to increase labor market participation of men from their average 20.5\% (see Appendix Table 7) to about $23 \%$ and of women from $19.3 \%$ to almost $20 \%$. According to Hypothesis 4, labor earnings elasticity is much higher for men than for women. ${ }^{26}$ Consistent with Hypothesis 2, an increase in pension entitlements by one percent significantly reduces the employment probability by 0.055 percentage points for women and 0.165 percentage points for men. Hochfellner and Burkert (2013) find a similar pattern by gender, their income elasticities are however somewhat lower. Pleau and Shauman (2013) find a smaller negative effect of retirement income on working after retirement for males than for females in their US sample, however. A higher pension entitlement leads to a stronger reduction in labor market participation for men than for women, accordingly.

The individual characteristics show the expected signs on employment after retirement (compare for example Burkert and Hochfellner 2017; Larsen and Pedersen 2013; Maestas 2010): employees who use bridge paths have a significantly lower probability to work and therefore labor market gaps before retirement have a negative correlation with labor market participation after retirement. Academics work less after retirement than skilled employees. Occupations before retirement hardly have an influence on working after retirement, however. ${ }^{27}$

These are the effects of the establishment characteristics of the last employer prior to retirement on the labor market decision of the retiree: workers who are employed in firms with more than ten employees prior to retirement show a lower labor force participation after retirement. Furthermore, there is a negative correlation between mean earnings of all full-time employees, the share of highly qualified employees, and the share of employees in partial retirement and work after retirement. The higher the share of employees who work after retirement at the last employer, the higher is the probability of being employed after retirement.

Note that the (potential) labor earnings regressor is generated because it has been estimated in a separate step with uncertainty (Borra 2010). Therefore, the standard errors of this variable are bootstrapped. A bivariate Probit model is used to verify the results of the linear probability model presented in Table 2 . The results of both estimation models are consistent with each other.

\footnotetext{
${ }^{26}$ We obtain larger coefficients for the estimated earnings variables in the labor participation equation if we drop the endogeneity correction (Mills ratio) in the earnings estimation step. (Potential) earnings however remain significant and larger for men than for women without controlling for endogeneity.

27 All results remain robust when only individual characteristics are included in the participation equation and employer characteristics are not controlled for.
}

Table 3 Linear probability model of labor force participation with the share of estimated earnings in disposable income

\begin{tabular}{lll}
\hline & Women & Men \\
\hline $\begin{array}{l}\text { Share of estimated earnings in } \\
\text { disposable income }\end{array}$ & $0.222^{* *}(0.054)$ & $0.816^{* *}(0.057)$ \\
$N$ & 30.784 & \\
$R^{2}$ & 0.306 & 44.887 \\
\end{tabular}

Same list of covariates as in Table 2. Standard errors in parentheses are computed by bootstrapping with 200 repetitions and clustered on the individual level. Data: SIAB 7514

${ }^{*} \mathrm{p}<0.05$

${ }^{* *} \mathrm{p}<0.01$

Table 4 Extensive margin of labor supply for employees with and without bridge paths

\begin{tabular}{|c|c|c|c|c|}
\hline & \multicolumn{4}{|l|}{ Bridge paths } \\
\hline & \multicolumn{2}{|l|}{ Women } & \multicolumn{2}{|l|}{ Men } \\
\hline & No & Yes & No & Yes \\
\hline $\begin{array}{l}\text { Estimated } \\
\text { earnings (log) }\end{array}$ & $0.095^{* *}(0.024)$ & $0.057^{*}(0.029)$ & $0.307^{* *}(0.095)$ & $\begin{array}{l}0.244^{* *} \\
(0.064)\end{array}$ \\
\hline$N$ & 19,887 & 10,897 & 19,223 & 25,664 \\
\hline$R^{2}$ & 0.407 & 0.067 & 0.287 & 0.071 \\
\hline
\end{tabular}

Same list of covariates as in Table 2. Standard errors in parentheses are computed by bootstrapping with 200 repetitions and clustered on the individual level. Data: SIAB 7514

${ }^{*} \mathrm{p}<0.05$

** $p<0.01$

The estimation equation in Table 3 replaces the separate labor earnings and pension entitlement variables by the share of earnings in disposable income. This variable has a substantial positive impact on the extensive margin of labor supply. An increase in the share of (potential) labor earnings in disposable income after retirement by one percentage point increases the probability of working beyond retirement by 0.22 percentage points for women and 0.82 percentage points for men. This result supports Hypothesis 3.

\subsection{Heterogeneity in earnings elasticities}

Table 4 shows differences in the estimated elasticity of labor force participation with respect to (potential) labor earnings between employees who use bridge paths versus those who do not use bridge paths prior to retirement. In line with Hypothesis 5 and prior empirical evidence (Anger et al. 2018; Burkert and Hochfellner 2017; Hochfellner and Burkert 2013), the estimates suggest a higher positive earnings effect on labor supply for employees without bridge paths than for employees with bridge paths. The earnings elasticities for employees without a bridge path are twice as large for women and 50\% larger 
Table 5 Extensive margin of labor supply for employees whose region of residence is the same as or different from the place of work

\begin{tabular}{|c|c|c|c|c|}
\hline & \multicolumn{4}{|c|}{ Region of residence is same as region of work } \\
\hline & \multicolumn{2}{|c|}{ Women } & \multicolumn{2}{|l|}{ Men } \\
\hline & No & Yes & No & Yes \\
\hline $\begin{array}{l}\text { Estimated } \\
\text { earnings } \\
\text { (log) }\end{array}$ & $\begin{array}{l}0.062^{* *} \\
(0.026)\end{array}$ & $0.080(0.083)$ & $\begin{array}{l}0.163^{* *} \\
(0.084)\end{array}$ & $0.234^{*}(0.146)$ \\
\hline N & 19,080 & 2289 & 25,799 & 6769 \\
\hline$R^{2}$ & 0.313 & 0.315 & 0.239 & 0.233 \\
\hline
\end{tabular}

List of covariates is the same as in Table 2. Number of observations lower than in Table 2 because region of residence is not reported for all employees. Standard errors in parentheses are computed by bootstrapping with 200 repetitions and clustered on the individual level. Data: SIAB 7514

${ }^{*} p<0.05$

${ }^{* *} p<0.01$

for men than those for employees with bridge paths, see Table 5. Employees without bridge paths therefore seem to derive lower utility from leisure and they are more responsive to financial incentives when deciding about employment after retirement.

When we compare earnings elasticities between employees who have to commute to work to a different region in their last employment prior to retirement and those who live and work in the same region, we use the approach proposed by Kropp and Schwengler (2016) to delineate 50 functional West German labor market regions based on commuting flows. ${ }^{28}$ The dummy has value one if an employee commutes to a workplace outside the own labor market region. Our results do not support Hypothesis 6: there are practically no differences between commuters and non-commuters for females and the differences between both employee groups are small for men, see Table $6 .^{29}$ We hardly find changes in the commuting situation before and after retirement. Commuting costs therefore seem not to play a central role for the labor supply decision of older employees for example in comparison to financial needs of older employees.

Our last sample split differentiates employees according to their earnings situation before exiting the labor market into retirement. According to Hypothesis 7, we find a higher elasticity of men in the lowest earnings quartile in comparison to men in the highest earnings quartile. For women, the lowest and highest earnings
Table 6 Extensive margin of labor supply for employees with low and high earnings before retirement

\begin{tabular}{|c|c|c|c|c|}
\hline & \multicolumn{4}{|c|}{ Earnings before retirement } \\
\hline & \multicolumn{2}{|l|}{ Women } & \multicolumn{2}{|l|}{ Men } \\
\hline & $\begin{array}{l}\text { Low } \\
\text { earnings }\end{array}$ & $\begin{array}{l}\text { High } \\
\text { earnings }\end{array}$ & $\begin{array}{l}\text { Low } \\
\text { earnings }\end{array}$ & $\begin{array}{l}\text { High } \\
\text { earnings }\end{array}$ \\
\hline $\begin{array}{l}\text { Estimated } \\
\text { ernings } \\
(\log )\end{array}$ & $0.084(0.045)$ & $0.063(0.039)$ & $\begin{array}{l}0.384^{* *} \\
(0.129)\end{array}$ & $0.097(0.110)$ \\
\hline N & 7441 & 7441 & 10.706 & 10,706 \\
\hline$R^{2}$ & 0.365 & 0.273 & 0.283 & 0.171 \\
\hline
\end{tabular}

High earnings are defined as earnings from the last employment subject to social insurance contributions with earnings above the 75 th percentile of all last earnings of employment subject to social insurance contributions. Low earnings are defined as earnings from the last employment subject to social insurance contributions with earnings less than 25th percentile of all last earnings of employment subject to social insurance contributions. List of covariates is the same as in Table 2. Standard errors in parentheses are computed by bootstrapping with 200 repetitions and clustered on the individual level. Data: SIAB 7514

${ }^{*} \mathrm{p}<0.05$

${ }^{* *} \mathrm{p}<0.01$

quartiles both have lower elasticities than the second and third earnings quartiles and therefore Hypothesis 7 is not supported for women. Our evidence only is in accordance with findings by Pleau (2010) and Pleau and Shauman (2013) for US men. They however find an increasing labor market supply elasticity with pre-retirement earnings for US women. The low labor supply elasticity of women with very low earnings before retirement may be a consequence of high alternative financial sources for example from other household members that we cannot observe in our data (Blundell et al. 2007; Micheel et al. 2010).

\section{Discussion and limitations}

Our paper uses the empirical identification approach developed for the employment decision of women with small children (Allègre et al. 2015; Borra 2010; Rammohan and Whelan 2007; Ribar 1992; Viitanen 2005). This literature mainly uses structural estimation models because there are hardly any quasi-natural experiments that can be exploited to obtain causal relationships between financial incentives and the employment decision. ${ }^{30}$ Also the literature on determinants for work after

\footnotetext{
28 The labor market regions are defined based on the place of work and the residential regions are defined based on the place of residence at the last employment prior to retirement.

29 The results remain robust when the information about place of work and place of residence are directly used from the dataset instead of the approach proposed by Kropp and Schwengler (2016).
}

\footnotetext{
${ }^{30}$ A notable exception is Bastani et al. (2021) who analyze the impact of a change in labor market participation tax rates on labor supply of secondary earners.
} 
retirement usually does not exploit quasi-natural experiments (Chetty et al. 2011). The main reason for the dearth of quasi-experimental evidence is that there were hardly any changes in the rules for labor earnings after retirement. In Germany, earnings beyond marginal employment have to be taxed at the common rates, marginal employment is tax free and the maximum earnings level for marginal employment was practically unchanged. ${ }^{31}$ In 2005 , a pension supplement of $6 \%$ per year of retirement after NRA was introduced for all pension entitlements. This option was used by a negligible share of retirees, however.

Besides using a structural approach our study is limited by several gaps in relevant information. Our data set does not report hours worked and we therefore only could analyze the extensive margin. Future work, as a consequence, should analyze retiree's labor supply respect to the number of hours worked conditional on employment (intensive margin). In addition, our administrative data only include pension entitlements derived from labor earnings. Future work therefore should include additional available financial means during retirement such as occupation pensions, additional pension entitlements for example from raising children or rent from wealth, assets, and real estate. Also considerable financial demands such as mortgage debt or financially dependent household have an important impact on the decision to work that is unobservable for us. Moreover, decisions about labor supply after retirement may result from considerations involving other individuals such as pension redistributions after a divorce or widow/widower pensions. Especially equivalent household income may be a more important driver for work after retirement than the individual financial situation. We know in addition that males and females react differently to financial stimuli within the household context (Blundell et al. 2007; Micheel et al. 2010). The distribution of wage elasticities of single childless women is very similar to that of men. It therefore is mainly married women and mothers who have higher wage elasticities (Bargain and Peichl 2016). As a consequence, also the household and marital situation and changes in behavior of household members not affected by financial incentive changes should be included in future research in order to get a full and unbiased picture of financial incentives for work after retirement.

Transferability of our results to other countries depends on the empirical question whether there are differences in labor supply elasticities between countries. It seems that there are little international differences in work preference (Bargain et al. 2014), although there for

\footnotetext{
${ }^{31}$ The maximum earnings level for minimum employment was increased on 1 January 2013 from $400 €$ to $450 €$, but further unchanged during our observation period.
}

example were marked differences with respect to the role of women on the labor market and in the household between East and West Germany before and shortly after the reunification of both countries (Sprengholz et al. 2020). In addition, there seems to be a secular reduction in wage elasticities over the last decades in many countries (Bargain and Peichl 2016). It therefore remains unclear what the influence of the observation period and institutional differences is for estimations of labor supply elasticities in other countries or in the Eastern part of Germany.

\section{Conclusions}

This paper provides a labor supply model for retirees and empirical assessments based on a large administrative labor market history data set. We for the first time use detailed information about labor earnings and non-labor income of a large administrative $2 \%$ sample of all employees after their retirement in Germany. We concentrate on the effect of labor earnings on the labor force participation beyond retirement and take endogeneity of the labor decision and heterogeneities between different employee groups into account.

We first establish that labor earnings achieved by pensioners after retirement constitute a substantial part of disposable income. The share of post-retirement earnings in disposable income is more than $60 \%$ for women and $50 \%$ for men. We then show that men are more responsive to financial incentives than women. A one percent increase in (potential) post-retirement labor earnings increases the employment probability of pensioners by 0.246 percentage points for males and by 0.056 percentage points for females. Labor earnings therefore have a strong incentive effect for work after retirement. Higher pension entitlements however lead to a negative labor participation effect. We analogously find that the higher the share of (potential) labor earnings in disposable income of the retiree, the higher is the labor force participation of the individual. We also show that individuals who work until retirement instead of using the bridge options unemployment or partial retirement as well as men with low earnings prior to retirement are stronger attracted by (potential) earnings incentives to work after retirement. Having to commute before retirement in contrast to residing in the same region as the place of work does not influence work participation after retirement, however.

Our analysis therefore shows that tax incentives or higher earnings offers by employers are most effective to stimulate labor market participation after retirement for males who earned not much before retirement and did not use bridge options. The calculation of the separate elasticities for labor earnings and pension eligibilities for example allows us the prediction of changes in financial incentives on work supply after retirement for different demographic groups. More 
specifically, our analysis shows that the gradual reduction of tax-free allowance to zero until 2040 that was induced by the Retirement Income Act 2004 (Genser and Holzmann 2019) may increase incentives to work after retirement. We also show that an increase in the tax-free allowance for work during pension also may have a positive effect for the older employees affected by the measure.

\section{Methods}

On the basis of theoretical hypotheses derived from a labor supply model, we propose an empirical choice model to examine the employment decision after receiving a pension. The decision to participate in the labor market is estimated based on a linear probability model using the employment status after retirement as the outcome variable. In order to impute (potential) labor earnings for all individuals included in the sample as explanatory variable, a two-step Heckman-type selection model is used. For the estimations, a sample of $2 \%$ of employees from the Integrated Employment Biographies from 1975 to 2014 (SIAB, 1975-2014) is used.

\section{Appendix}

See Tables 7, 8, 9, and 10.

Table 7 Number and share of individuals who work beyond retirement by birth cohort

\begin{tabular}{llllll}
\hline Birth cohort & \multicolumn{2}{l}{ Women } & & Men & \\
\cline { 2 - 3 } \cline { 6 - 6 } & N & Share & & N & Share \\
\hline Average & 2056 & 0.193 & & 3180 & 0.205 \\
1935 & 1934 & 0.192 & & 3075 & 0.204 \\
1936 & 1992 & 0.202 & 3142 & 0.215 \\
1937 & 2384 & 0.206 & 3586 & 0.178 \\
1938 & 2675 & 0.197 & 3933 & 0.207 \\
1939 & 2582 & 0.206 & 4091 & 0.193 \\
1940 & 2807 & 0.174 & 4306 & 0.200 \\
1941 & 2783 & 0.192 & 4052 & 0.196 \\
1942 & 2336 & 0.194 & 3292 & 0.201 \\
1943 & 2330 & 0.204 & 3334 & 0.215 \\
1944 & 2418 & 0.208 & 3201 & 0.206 \\
1945 & 1775 & 0.235 & 2551 & 0.254 \\
1946 & 2264 & 0.223 & 2934 & 0.261 \\
1947 & 2504 & 0.229 & 3390 & 0.265 \\
\hline
\end{tabular}

Data: SIAB 7514

Table 8 Sample characteristics

\begin{tabular}{|c|c|c|c|c|c|c|}
\hline & \multicolumn{6}{|c|}{ Work beyond retirement } \\
\hline & \multicolumn{3}{|l|}{ Women } & \multicolumn{3}{|l|}{ Men } \\
\hline & No & Yes & Diff. & No & Yes & Diff. \\
\hline \multicolumn{7}{|l|}{ Employee characteristics prior to retirement } \\
\hline Pension entitlements & $790.119(314.7)$ & $696.246(278.6)$ & $93.872^{* *}(4.354)$ & $1283.311(414.2)$ & $1183.442(355.01)$ & $99.869 * *(4.641)$ \\
\hline Estimated earnings (log) & $-0.016(0.982)$ & $1.082(0.593)$ & $1.098^{* *}(0.013)$ & $1.236(0.618)$ & $1.710(0.498)$ & $0.474^{* *}(0.007)$ \\
\hline Observed earnings (log) & & $2.352(0.721)$ & & & $2.520(0.887)$ & \\
\hline Share of unemployment bridge path & $0.258(0.438)$ & $0.159(0.365)$ & $0.099 * *(0.006)$ & $0.409(0.492)$ & $0.250(0.433)$ & $0.160^{* *}(0.006)$ \\
\hline Share of partial retirement bridge path & $0.136(0.342)$ & $0.045(0.207)$ & $0.091^{* *}(0.005)$ & $0.223(0.416)$ & $0.109(0.312)$ & $0.114^{* *}(0.005)$ \\
\hline Manufacturing occupations & $0.175(0.380)$ & $0.143(0.350)$ & $0.033^{* *}(0.006)$ & $0.550(0.498)$ & $0.468(0.499)$ & $0.082^{* *}(0.006)$ \\
\hline Service occupations & $0.308(0.462)$ & $0.356(0.479)$ & $0.048^{* *}(0.007)$ & $0.188(0.390)$ & $0.289(0.453)$ & $0.101^{* *}(0.005)$ \\
\hline Administrative occupations & $0.517(0.500)$ & $0.502(0.500)$ & $0.015^{*}(0.007)$ & $0.262(0.440)$ & $0.244(0.429)$ & $0.019^{* *}(0.005)$ \\
\hline $\begin{array}{l}\text { Accumulated labor market gaps prior to } \\
\text { age } 65 \text { in months }\end{array}$ & $32.777(25.380)$ & $4.309(13.736)$ & $28.468^{* *}(0.332)$ & 19.575 (22.322) & $3.438(11.382)$ & $16.137^{* *}(0.236)$ \\
\hline \multicolumn{7}{|c|}{ Characteristics of last employer prior to retirement } \\
\hline Firm size & $681.909(2400.6)$ & $366.367(1549.8)$ & $315.5^{*}(31.885)$ & $1788.5(5732.3)$ & $952.760(4163.6)$ & $835.7^{* *}(62.703)$ \\
\hline $\begin{array}{l}\text { Mean imputed earnings of all full-time } \\
\text { employees }\end{array}$ & $89.652(33.863)$ & $80.465(32.472)$ & $9.188^{* *}(0.475)$ & $108.250(44.180)$ & $96.706(38.056)$ & $12.54^{* *}(0.495)$ \\
\hline Share of highly qualified employees & $0.116(0.162)$ & $0.088(0.145)$ & $0.029^{* *}(0.002)$ & $0.131(0.161)$ & $0.098(0.144)$ & $0.033^{* *}(0.002)$ \\
\hline Share of employees in partial retirement & $0.015(0.038)$ & $0.008(0.028)$ & $0.007^{* *}(0.0005)$ & $0.022(0.045)$ & $0.015(0.043)$ & $0.007^{* *}(0.0005)$ \\
\hline Share of employees aged of 55 to 59 & $0.133(0.135)$ & $0.120(0.134)$ & $0.012^{* *}(0.002)$ & $0.121(0.110)$ & $0.113(0.110)$ & $0.008^{* *}(0.001)$ \\
\hline Share of employees aged of 60 to 64 & $0.059(0.105)$ & $0.083(0.137)$ & $0.024^{* *}(0.002)$ & $0.057(0.098)$ & $0.077(0.123)$ & $0.020^{* *}(0.001)$ \\
\hline Share of employees aged 65 and older & $0.012(0.039)$ & $0.032(0.081)$ & $0.020(0.0007)$ & $0.009(0.036)$ & $0.028(0.078)$ & $0.020^{* *}(0.0005)$ \\
\hline$N$ & 24,511 & 6273 & 30,784 & 35,338 & 9549 & 44,887 \\
\hline
\end{tabular}

Mean is given for continuous variables. Standard deviations of the continuous variables and standard errors for the mean value differences are given in parentheses. Data: SIAB 7514 
Table 9 Correlations between previous labor market experience and estimated as well as observed earnings

Pension entitlements (log)

Women

$\begin{array}{lrr}\text { Estimated earnings (log) } & -0.1117 & -0.0277 \\ \text { Observed earnings after retirement (log) } & 0.1582 & 0.2299 \\ \text { Men } & & 0.0592 \\ \text { Estimated earnings (log) } & 0.0979 & 0.1962 \\ \text { Observed earnings after retirement }(\mathrm{log}) & 0.1494 & \end{array}$

Table 10 Auxiliary estimations

\begin{tabular}{|c|c|c|c|c|c|c|c|c|}
\hline & Women & Men & & & & & & \\
\hline Observations & 30,784 & 44,887 & & & & & & \\
\hline Censored observations & 24,511 & 35,338 & & & & & & \\
\hline Uncensored observations & 6273 & 9549 & & & & & & \\
\hline Log likelihood & $-11,791$ & $-19,581$ & & & & & & \\
\hline$x^{2}(9)$ & 7545.47 & 7300.83 & & & & & & \\
\hline \multirow[t]{3}{*}{ Prob > $x^{2}$ : } & 0.2424 & 0.000 & & & & & & \\
\hline & \multicolumn{2}{|c|}{ Labour force participation } & \multirow[t]{2}{*}{ Log wage } & & \multicolumn{2}{|c|}{ Labour force participation } & \multirow[t]{2}{*}{ Log wage } & \\
\hline & Coef. & SE & & & Coef. & SE & & \\
\hline Constant & $1.292^{* *}$ & 0.176 & $-0.637^{* *}$ & 0.201 & $1.186^{* *}$ & 0.0171 & $-1.320^{* *}$ & 0.211 \\
\hline No degree & Ref. & Ref. & Ref. & Ref. & Ref. & Ref. & Ref. & Ref. \\
\hline Vocational training & $0.227^{* *}$ & 0.027 & $0.231^{* *}$ & 0.041 & $0.378^{* *}$ & 0.028 & $0.231^{* *}$ & 0.043 \\
\hline University degree & 0.043 & 0.049 & $0.351^{* *}$ & 0.062 & $0.149^{* *}$ & 0.034 & $0.566^{* *}$ & 0.046 \\
\hline Manufacturing occupations & Ref. & Ref. & Ref. & Ref. & Ref. & Ref. & Ref. & Ref. \\
\hline Service occupations & $0.228^{* *}$ & 0.029 & $0.261^{* *}$ & 0.046 & $0.253^{* *}$ & 0.018 & $0.223^{* *}$ & 0.029 \\
\hline Administrative occupations & $0.096^{* *}$ & 0.028 & $0.239 * *$ & 0.037 & $0.073^{* *}$ & 0.018 & $0.198^{* *}$ & 0.023 \\
\hline $\begin{array}{l}\text { Acc. labor market gaps until } 65 \\
\text { in months }\end{array}$ & $-0.033^{* *}$ & 0.0006 & $-0.035^{* *}$ & 0.004 & $-0.031^{* *}$ & 0.0005 & $-0.022^{* *}$ & 0.002 \\
\hline Pension entitlements (log) & $-0.275^{* *}$ & 0.025 & & & $-0.494^{* *}$ & 0.024 & & \\
\hline Lambda & & & $1.205^{* *}$ & 0.157 & & & $0.705^{* *}$ & 0.084 \\
\hline \multicolumn{9}{|l|}{ Hausman test } \\
\hline $\mathrm{Chi}^{2}(8)$ & 57.73 & & & & 69.00 & & & \\
\hline Prob > chi²: & 0.0000 & & & & 0.0000 & & & \\
\hline
\end{tabular}

In both equations, year of employment exit prior to the age of 65 is controlled for. SE: standard error. Data: SIAB 7514

${ }^{*} \mathrm{p}<0.05$

${ }^{* *} \mathrm{p}<0.01$

\section{Acknowledgements}

We are grateful to Mona Bruns for helpful discussions on this paper.

\section{Authors' contributions}

Both authors contributed in equal shares to the paper. Both authors read and approved the final manuscript.

\section{Funding}

Not applicable.

\section{Availability of data and materials}

The paper uses the SIAB7514. Data access was provided via on site use at the Research Data Centre (FDZ) of the German Federal Employment Agency (BA) at the Institute for Employment Research (IAB) and subsequently via remote data access. These data are publicly available.

\section{Declarations}

Ethics approval and consent to participate

Not applicable.

Consent for publication

Not applicable. 


\section{Competing interests \\ Not applicable.}

\section{Author details}

${ }^{1}$ Faculty of Business Management and Economics, University of Würzburg, Sanderring 2, 97070 Würzburg, Germany. ${ }^{2}$ ZEW Leibniz Centre for European Economic Research, Mannheim, Germany. ${ }^{3}$ Research Centre for Education and the Labour Market, University of Maastricht, Maastricht, The Netherlands.

Received: 12 April 2021 Accepted: 21 September 2021

Published online: 07 October 2021

\section{References}

Allègre, G., Simonnet, V., Sofer, C.: Child care and labor market participation in France: do monetary incentives matter? Ann. Econ. Stat. 117(118), 115-139 (2015)

Anger, S., Trahms, A., Westermeier, C.: Erwerbstätigkeit nach dem Übergang in Altersrente: Soziale Motive überwiegen, aber auch Geld ist wichtig. IABKurzbericht, 24/2018. Nuremberg (2018)

Antoni, M., Ganzer, A., vom Berge, P.: Stichprobe der Integrierten Arbeitsmarktbiografien (SIAB) 1975-2014. FDZ Datenreport, 04/2016. Nuremberg (2016)

Bäcker, G., Jansen, A., Schmitz, J.: Rente erst ab 70? Probleme und Perspektiven des Altersübergangs. IAQ-Forschung 2017-02. University of DuisburgEssen (2017)

Bargain, O., Orsini, K., Peichl, A.: Comparing labor supply elasticities in Europe and the United States-new results. J. Hum. Resour. 49(3), 723-838 (2014)

Bargain, O., Peichl, A.: Own-wage labor supply elasticities: variation across time and estimation methods. IZA J. Labor Econ. 5(10), 1-31 (2016)

Bastani, S., Moberg, Y., Selin, H.: The anatomy of the extensive margin labor supply response. Scand. J. Econ. 123(1), 33-59 (2021)

Beehr, T., Bennett, M.: Working after retirement: features of bridge employment and research directions. Work Aging Retire. 1(1), 112-128 (2015)

Blau, F., Kahn, L.: Changes in the labor supply behavior of married women: 1980-2000. J. Law Econ. 25(3), 393-438 (2007)

Blossfeld, H.P.: Berufseintritt und Berufsverlauf. Mitt. Arbeitsmarkt Berufsforsch. 18(2), 177-197 (1985)

Blundell, R., Chiappori, P., Magnac, T., Meghir, C.: Collective labour supply: heterogeneity and non-participation. Rev. Econ. Stud. 74(2), 417-445 (2007)

Borra, C.: Childcare costs and Spanish mothers' labor force participation. Hacienda Pública Española/revista De Economía Pública 194(3), 9-40 (2010)

Brenke, K.: Immer mehr Menschen im Rentenalter sind berufstätig. DIW Wochenbericht 80(6), 3-12 (2013)

Brussig, M.: Erwerbstätigkeit im Alter hängt vom Beruf ab. AltersübergangsReport, 2010-05. University of Duisburg-Essen (2010)

Brussig, M.: Alter beim Austritt aus sozialversicherungspflichtiger Beschäftigung ist gestiegen. Altersübergangs-Report, 2015-01 (2015)

Brussig, M., Bellmann, L.: Betriebliche Einflussfaktoren auf Rekrutierungen Älterer und deren Bewerbungen. German J. Hum. Resour. Manag. 22(1) 35-57 (2008)

Burkert, C., Hochfellner, D.: Employment trajectories beyond retirement. J. Aging Soc. Policy 29(2), 143-167 (2017)

Büsch, V., Dorbritz, J., Heien, T., Micheel, F.: Weiterbeschäftigung im Rentenalter: Wünsche, Bedingungen, Möglichkeiten. Materialien zur Bevölkerungswissenschaft, 129/2010 (2010)

Cahill, K., Giandrea, M., Quinn, J.: Retirement patterns and the macroeconomy, 1992-2010: the prevalence and determinants of bridge jobs, phased retirement, and reentry among three recent cohorts of older Americans. Gerontologist 55(3), 384-403 (2015)

Cahuc, P., Carcillo, S., Zylberberg, A.: Labor Economics. MIT press, Cambridge (2004)

Cameron, C., Trivedi, P.: Microeconometrics-Methods and Applications. Cambridge University Press, Cambridge (2002)

Chetty, R., Guren, A., Manoli, D., Weber A.: Does indivisible labor explain the difference between micro and macro elasticities? A meta-analysis of extensive margin elasticities. NBER Working Paper 16729. Cambridge MA (2011)
Cogan, J.F.: Labor supply with time and money costs of participation. Rand Report R-2044-HEW. Santa Monica CA (1977)

Cogan, J.F.: Fixed costs and labor supply. Econometrica 49(4), 945-963 (1981)

Connelly, R.: The effect of child care costs on married women's labor force participation. Rev. Econ. Stat. 74(1), 83-90 (1992)

Connelly, R., Kimmel, J.: Marital status and full-time/part-time work status in child care choices. Appl. Econ. 35(7), 761-777 (2003)

Del Boca, D., Vuri, D.: The mismatch between employment and child care in Italy: the impact of rationing. J. Popul. Econ. 20(4), 805-832 (2007)

Dittrich, D., Büsch, V., Micheel, F.: Working beyond retirement age in Germany: the employee's perspective. In: Ennals, R., Salomon, R. (eds.) Older Workers in a Sustainable Society, pp. 189-202. Peter Lang, Frankfurt am Main (2011)

Engstler, H., Romeu-Gordo, L.: Arbeiten im Ruhestand-Entwicklung, Faktoren und Motive der Erwerbstätigkeit von Altersrentenbeziehern. In: Kistler, E., Trischler, F. (eds) Reformen auf dem Arbeitsmarkt und in der Alterssicherung-Folgen für die Einkunftslage im Alter. edition der Hans-Böckler-Stiftung, Arbeit und Soziales 196, Düsseldorf, pp. 115-147 (2014)

Engstler, H., Romeu-Gordo, L.: Der Übergang in den Ruhestand: Alter, Pfade und Ausstiegspläne. In: Mahne, K., Wolff, C., Simonson, J., Tesch-Römer, C. (eds.) Altern im Wandel, pp. 65-80. Springer, Wiesbaden (2017)

Erlinghagen, M.: Entlassungen und Beschäftigungssicherheit im Zeitverlauf. Z. Soziol. 34(2), 147-168 (2005)

Eurofound: Income From Work After Retirement in the EU. Publications Office of the European Union, Luxembourg (2012)

Evers, M., De Mooij, R., van Vuuren, D.: What explains the variation in estimates of labor supply elasticities? Ifo Institute for Economic Research Working Paper Series, 1633. Munich (2005)

Fasbender, U., Wang, M., Voltmer, J.B., Deller, J.: The meaning of work for postretirement employment decisions. Work Aging Retire. 2(1), 12-23 (2016)

Genser, B. Holzmann, R.: Taxing German old-age pensions fairly and efficiently, ifo DICE report volume 17. Munich (2019)

Geyer, J., Haan, P., Lorenz, S., Zwick, T. Bruns, M.: The role of labor demand in the labor market effects of pension reforms. Industrial Relations, forthcoming (2021)

Grund, C.: Severance payments for dismissed employees in Germany. Eur. J. Law Econ. 22(1), 49-71 (2006)

Gutiérrez-i-Puigarnau, E., van Ommeren, J.: Labour supply and commuting. J. Urban Econ. 68(1), 82-89 (2010)

Hanel, B.: Financial incentives to postpone retirement and further effects on employment_evidence from a natural experiment. Labour Econ. 17(3), 474-486 (2010)

Hank, K., Buber, I.: Grandparents caring for their grandchildren: findings from the 2004 survey of health, ageing, and retirement in Europe. J. Fam. Issues 30(1), 53-73 (2009)

Heckman, J.: The common structure of statistical models of truncation, sample selection and limited dependent variables and a simple estimator for such models. Ann. Econ. Soc. Meas. 5(4), 475-492 (1976)

Heckman, J.: Sample selection bias as a specification error. Econometrica 47(1), 153-161 (1979)

Hochfellner, D., Burkert, C.: Berufliche Aktivität im Ruhestand. Z. Gerontol. Geriatr. 46(3), 242-250 (2013)

Hofäcker, D., Naumann, E.: The emerging trend of work beyond retirement age in Germany. Z. Gerontol. Geriatr. 48(5), 473-479 (2015)

Institut für Arbeit und Qualifikation.: Erwerbstätige nach Stellung im Beruf 1994-2019. Sozialpolitik aktuell in Deutschland, University of DuisburgEssen (2020)

Kanabar, R.: Post-retirement labour supply in England. J. Econ. Ageing 6 123-132 (2015)

Kim, S., Feldmann, D.C.: Working in retirement: the antecedents of bridge employment and its consequences for quality of life in retirement. Acad. Manag. J. 43(6), 1195-1210 (2000)

Komp, K., van Tilburg, T., Broese van Groenou, M.: Paid work between age 60 and 70 years in Europe: a matter of socio-economic status? Int. J. Ageing Later Life 5(1), 45-75 (2010)

Kropp, P., Schwengler, B.: Three-step method for delineating functional labor market regions. Reg. Stud. 50(3), 429-445 (2016)

Larsen, M., Pedersen, P.: To work, to retire- or both? Labor market activity after 60. IZA J. Eur. Labor Stud. 2, 21 (2013) 
Lorenz, S., Pfister, M., Zwick T.: Identification of the statutory retirement dates in the Sample of Integrated Labor Market Biographies (SIAB). FDZ Methodenreport, 08/2018. Nuremberg (2018)

Lorenz, S., Pfister, M., Zwick, T.: Beware of the employer: financial incentives for employees may fail to prolong old-age employment. ZEW Discussion Paper, 20-007. Mannheim (2020)

Maestas, N.: Back to work: expectations and realizations of work after retirement. J. Hum. Resour. 45(3), 718-748 (2010)

Maxin, L., Deller, J.: Activities in retirement: individual experience of silver work. Comp. Popul. Stud. 35(4), 801-832 (2010)

Meyer, B., Rosenbaum, D.: Welfare, the earned income tax credit, and the labor supply of single mothers. Q. J. Econ. 116(3), 1063-1114 (2001)

Micheel, F.: The intention to paid and/or unpaid activities in retirement-a study of older workers in Germany. J. Aging Soc. Policy 33(2), 101-119 (2021)

Micheel, F., Cihlar, V., Riedl, S.: "Der Geist ist willig, aber..."-Was Menschen daran hindert, im Ruhestand zu arbeiten. Bevölkerungsforschung Aktuell, 6/2017, 2-9 (2017)

Micheel, F., Roloff, J., Wickenheiser, l.: The impact of socioeconomic characteristics on older employees' willingness to continue working in retirement age. Comp. Popul. Stud. Zeitschrift Für Bevölkerungswissenschaft 35(4), 869-902 (2010)

Mincer, J.: Labor force participation of married women. In: Lewis, H. (ed.) Aspect of Labor Economics. Universities National Bureau of Economic Research Conference Series, vol. 14, pp. 63-105. Princeton University Press, Princeton (1962)

Pfarr, C., Maier, C.: Arbeit trotz Rente: Warum bleiben Menschen in Ruhestand erwerbstätig. Deutsches Institut für Altersvorsorge, Berlin (2015)

Pfister, M., Lorenz, S., Zwick, T.: Implementation of pension entitlements in the sample of integrated labor market biographies (SIAB). FDZ Methodenreport, 01/2018. Nuremberg (2018)

Pleau, R.: Gender differences in postretirement employment. Res. Aging 32(3), 267-303 (2010)

Pleau, R., Shauman, K.: Trends and correlates of post-retirement employment, 1977-2009. Hum. Relat. 66(1), 113-141 (2013)

Rammohan, A., Whelan, S.: The Impact of childcare costs on the full-time/parttime employment decisions of Australian mothers. Australian Economic Papers 46(2), 152-169 (2007)

Rasner, A., Etgeton, S.: Rentenübergangspfade: Reformen haben großen Einfluss. DIW-Wochenbericht 81(19), 431-441 (2014)

Rhein, T:: Arbeiten im Rentenalter: Erwerbstätigkeit 65plus in Europa. Aktuelle Berichte, 25/2016. Institute for Employment Research, Nuremberg (2016)
Ribar, D.C.: Child care and the labor supply of married women: reduced form evidence. J. Hum. Resour. 27(1), 134-165 (1992)

Rogerson, R., Wallenius, J.: Micro and macro elasticities in a life cycle model with taxes. J. Econ. Theory 144(6), 2277-2292 (2009)

Saba, T., Guerin, G.: Extending employment beyond retirement age: the case of health care managers in Quebec. Public Pers. Manag. 34, 195-214 (2005)

Schellenberg, G., Turcotte, M., Ram, B.: Post-retirement employment. Stat. Can. Perspect. 75-001, 14-17 (2005)

Schmähl, W.: Ageing workforce: firm strategies and public policy in Germany. Geneva Pap. Risk Insur. 28(4), 575-595 (2003)

Smeaton, D., McKay, S.: Working after state pension age: quantitative analysis. UK Department for Work and Pensions Research Report 182. London (2003)

Sprengholz, M., Wieber, A., Holst, E.: Gender identity and wives' labor market outcomes in West and East Germany between 1983 and 2016. SocioEcon. Rev. (2020). https://doi.org/10.1093/ser/mwaa048

Sullivan, S.E., Al Ariss, A.: Employment after retirement: a review and framework for future research. J. Manag. 45(1), 262-284 (2019)

Torka, N., Goedegebure, I., Van Ewijk, I., Looise, J.: On the motives and needs for work beyond age 65: comparing voluntary workers versus agency workers. German J. Hum. Resour. Manag. 26(2), 167-188 (2012)

Ullmann, K., Bothfeld, S.: The German employment protection act-how does it work in company practice? WSI Discussion Paper 161, Duesseldorf (2008)

Vargha, L., Gál, R., Crosby-Nagy, M.: Household production and consumption over the life cycle: national time transfer accounts in 14 European countries. Demogr. Res. 36(32), 905-944 (2017)

Viitanen, T.K.: Cost of childcare and female employment in the UK. Labour 19, 149-170 (2005)

Wang, M., Zhan, Y., Liu, S., Shultz, K.: Antecedents of bridge employment: a longitudinal investigation. J. Appl. Psychol. 93(4), 818-830 (2008)

Wanger, S.: Altersteilzeit: Beliebt, aber nicht zukunftsgerecht. IAB-Kurzbericht, 08/2009 (2009)

Westermeier, C.: Ältere am Arbeitsmarkt. Eine stabile Beschäftigung vor dem Rentenalter begünstigt die Weiterarbeit. IAB-Kurzbericht, 15/2019 (2019)

\section{Publisher's Note}

Springer Nature remains neutral with regard to jurisdictional claims in published maps and institutional affiliations.

\section{Submit your manuscript to a SpringerOpen ${ }^{\circ}$ journal and benefit from:}

- Convenient online submission

- Rigorous peer review

- Open access: articles freely available online

- High visibility within the field

Retaining the copyright to your article

Submit your next manuscript at springeropen.com 